\title{
Long-term succession of benthic infauna communities on constructed Spartina alterniflora marshes
}

\author{
Christopher Craft ${ }^{1, *}$, John Sacco ${ }^{2}$ \\ ${ }^{1}$ School of Public and Environmental Affairs, Indiana University, Bloomington, Indiana 47405, USA \\ ${ }^{2}$ Office of Natural Resources Restoration, New Jersey Department of Environmental Protection, Trenton, New Jersey 08625, USA
}

\begin{abstract}
Benthic infauna communities were characterized along a chronosequence (1 to $28 \mathrm{yr}$ old) of 7 constructed Spartina alterniflora Loisel marshes and 7 natural (reference) marshes to identify patterns of succession following salt marsh creation. Infauna density and species richness (per $7.07 \mathrm{~cm}^{2}$ core) achieved equivalence to comparable reference marshes within $8 \mathrm{yr}$ following marsh creation. Taxa with dispersing larval stages (e.g. Streblospio benedicti, Capitella sp.) achieved equivalence within 3 yr following marsh creation. Taxa that lack a planktonic dispersal stage, such as tubificid oligochaetes and Manayunkia aesturina, were slower to develop. Densities of Manayunkia did not achieve equivalence to natural marshes until $8 \mathrm{yr}$ after marsh creation. Twenty-five yr elapsed before oligochaete densities of constructed marshes were similar to natural marshes. In constructed marshes, densities of surface-deposit feeders, dominated by Streblospio and Manayunkia, achieved equivalence to natural marshes within $8 \mathrm{yr}$ following marsh creation. Subsurface-deposit feeders, consisting mostly of oligochaetes, did not become equivalent to natural marshes for 25 yr. Predictable trajectories, described by an asymptotic increase over time, existed for total species, species richness, and surface- and subsurface-deposit feeders. Oligochaetes and Manayunkia, which produce nondispersing larvae, exhibited linear trajectories over time. In constructed marshes, total density and density of dominant taxa and trophic groups were strongly correlated with soil characteristics, especially organic $\mathrm{C}, \mathrm{N}$, bulk density and macro-organic matter (MOM, the living and dead root and rhizome mat). Non-linear regressions using soil organic $\mathrm{C}$ and MOM explained 38 to $40 \%$ of the variation in constructed marsh infauna density. The regressions suggest that a threshold of $0.5 \%$ soil organic $\mathrm{C}\left(500 \mathrm{~g} \mathrm{~m}^{-2}, 0\right.$ to $\left.10 \mathrm{~cm}\right)$ and $500 \mathrm{~g} \mathrm{MOM} \mathrm{m}^{-2}(0$ to $10 \mathrm{~cm})$ is needed to support infauna densities comparable to densities found in natural marshes. Taxon richness of constructed marshes was more strongly related to vegetation characteristics, especially macro-organic matter quality (e.g. lignin) than soil characteristics. Development of benthic infauna communities following marsh construction requires longer than the 5 yr monitoring period required by many wetland mitigation plans, and as much as $25 \mathrm{yr}$ are needed for some attributes (e.g. oligochaetes) to achieve equivalence.
\end{abstract}

KEY WORDS: Wetland creation - Restoration $\cdot$ Rehabilitation $\cdot$ Ecosystem development $\cdot$ Chronosequence $\cdot$ Reference wetland $\cdot$ Salt marshes $\cdot$ North Carolina

\section{INTRODUCTION}

Benthic and aquatic invertebrates are frequently used as indicators of ecosystem health to assess biotic integrity of aquatic and wetland ecosystems (Lenat 1988, Lang et al. 1989, Karr 1991, Kerans \& Karr 1994, Spieles \& Mitsch 2000). In estuarine wetlands, benthic invertebrates also are used to assess the development of secondary production and food web support following salt marsh creation and restoration (Moy \& Levin 1991, Sacco et al. 1994, Levin et al. 1996, Scatolini \& Zedler 1996, Simenstad \& Thom 1996, Minello \& Webb 1997, Craft et al. 1999, Talley \& Levin 1999). Most studies to date indicate that infauna community composi- 
tion is slow to develop, requiring years to achieve equivalence to natural marshes (LaSalle et al. 1991, Moy \& Levin 1991, Minello \& Zimmerman 1992, Sacco et al. 1994, Levin et al. 1996, Scatolini \& Zedler 1996, Minello \& Webb 1997) and some (tubificid) oligochaetes are especially slow to develop (Moy \& Levin 1991, Levin et al. 1996). Levin et al. (1996) reported that 4 yr after marsh construction, oligochaetes, which comprised more than $50 \%$ of the infauna in a nearby natural marsh, were rare or absent from the constructed marsh. The slow rate of colonization by infauna, and oligochaetes in particular, is attributed to the absence of a planktonic dispersal stage (Levin et al. 1996) as well as low organic-matter content of constructed marsh soils (Moy \& Levin 1991, Levin et al. 1996, Craft 2000, Broome et al. 2001).

In spite of the importance of benthic infauna as an indicator of structural/functional equivalence following salt marsh creation and restoration, little is known about long-term succession of the community. Posey et al. (1997) and Alphin \& Posey (2000) reported that benthic infauna communities of 3 Spartina alterniflora constructed marshes in South Carolina, ranging in age from 6 to 24 yr old, had qualitatively similar species composition as natural marshes, although in these studies, natural marshes were not directly compared. Comparison of 16 mo to $10 \mathrm{yr}$ old Salicornia-vegetated marshes in southern California also indicated relatively rapid development of the infauna community (Talley \& Levin 1999). In this study, densities of infauna, with the exception of tubificid oligochaetes, achieved equivalence to natural Salicornia marshes within 5 to $10 \mathrm{yr}$ following marsh creation. Craft et al. (1999) reported that two 20 to 25 yr old constructed $S$. alterniflora Loisel marshes contained infaunal density, diversity and trophic structure comparable to 2 natural reference marshes sampled at the same time. However, this study did not determine whether infauna populations were self-sustaining on these marshes, nor was it possible from this study to identify trajectories of successional development over time.

We compared infauna community composition along a chronosequence of 7 constructed Spartina alterniflora marshes that varied in age from 1 to $28 \mathrm{yr}$ to elucidate patterns of development of (1) density and taxon richness, (2) dominant taxa and (3) feeding groups, and (4) to identify the relationship between infuana community development and edaphic (soil \& vegetation) factors following salt marsh construction. Each constructed marsh was paired with a natural reference marsh that was sampled at the same time to provide a benchmark for assessing the degree of convergence towards full or complete equivalence.

Our measured parameters characterize the development of infauna structure (e.g. density, taxon richness) following marsh construction. Wetland managers, however, are more interested in restoring functional attributes such as food web support that are assessed by other measurements such as infauna biomass and secondary production. Thus, it is important to recognize that measurements of infauna density serve as an index of functional development of benthic infauna communities.

\section{MATERIALS AND METHODS}

Site description. We used the chronosequence approach to evaluate succession of benthic infauna following salt marsh construction. In this study, we sampled benthic invertebrates from 7 constructed marshes that had similar tidal inundation, salinity, vegetation and soils but differed with respect to age (Table 1). Between 1970 and 1997, salt marsh wetlands were constructed along the North Carolina coast for a variety of purposes, including dredge spoil and shoreline stabilization, and mitigation of wetland loss (Fig. 1). Marshes were constructed by grading to intertidal elevation, then planting at elevations between mean sea level (MSL) and mean high water with cordgrass Spartina alterniflora (Broome et al. 1988). Tidal amplitude ranged between 1.0 and $1.2 \mathrm{~m}$ MSL at all sites.

The strength of the chronosequence approach is that it 'compresses' time, avoiding the need for long-term repeated measurements on a single site. A limitation of the approach is that, because of variable disturbance histories, differences among sites may be incorrectly attributed to ecosystem development rather than past

Table 1. Characteristics of constructed and natural salt marshes. Marshes were constructed for mitigation on dredge spoil (Marshes 1 and 2), research (Marsh 3), mitigation on graded upland soil (Marsh 4), shoreline stabilization (Marsh 5) and dredge spoil stabilization (Marshes 6 and 7). Age and size refer to constructed marshes

\begin{tabular}{|lcccl|}
\hline Marsh & $\begin{array}{l}\text { Age } \\
\text { (yr) }\end{array}$ & $\begin{array}{l}\text { Size } \\
\text { (ha) }\end{array}$ & $\begin{array}{l}\text { Salinity } \\
\left(\mathrm{g} \mathrm{l}^{-1}\right)\end{array}$ & $\begin{array}{l}\text { Geomorphic } \\
\text { position }\end{array}$ \\
\hline (1) DOT & 1 & 0.9 & $20-30$ & Back barrier flats \\
(2) Consultant & 3 & 1.0 & $17-32$ & Back barrier flats \\
(3) Port & 8 & 1.0 & $18-30$ & Back barrier flats \\
(4) Dill's Creek & 13 & 0.3 & $14-33$ & Submerged upland \\
(5) Pine Knoll & 24 & 0.3 & $20-30$ & Back barrier fringe \\
(6) Marine Lab & 26 & 0.2 & $20-30$ & Back barrier flats \\
(7) Snow's Cut & 28 & 0.8 & $5-20$ & Riverine \\
\hline
\end{tabular}




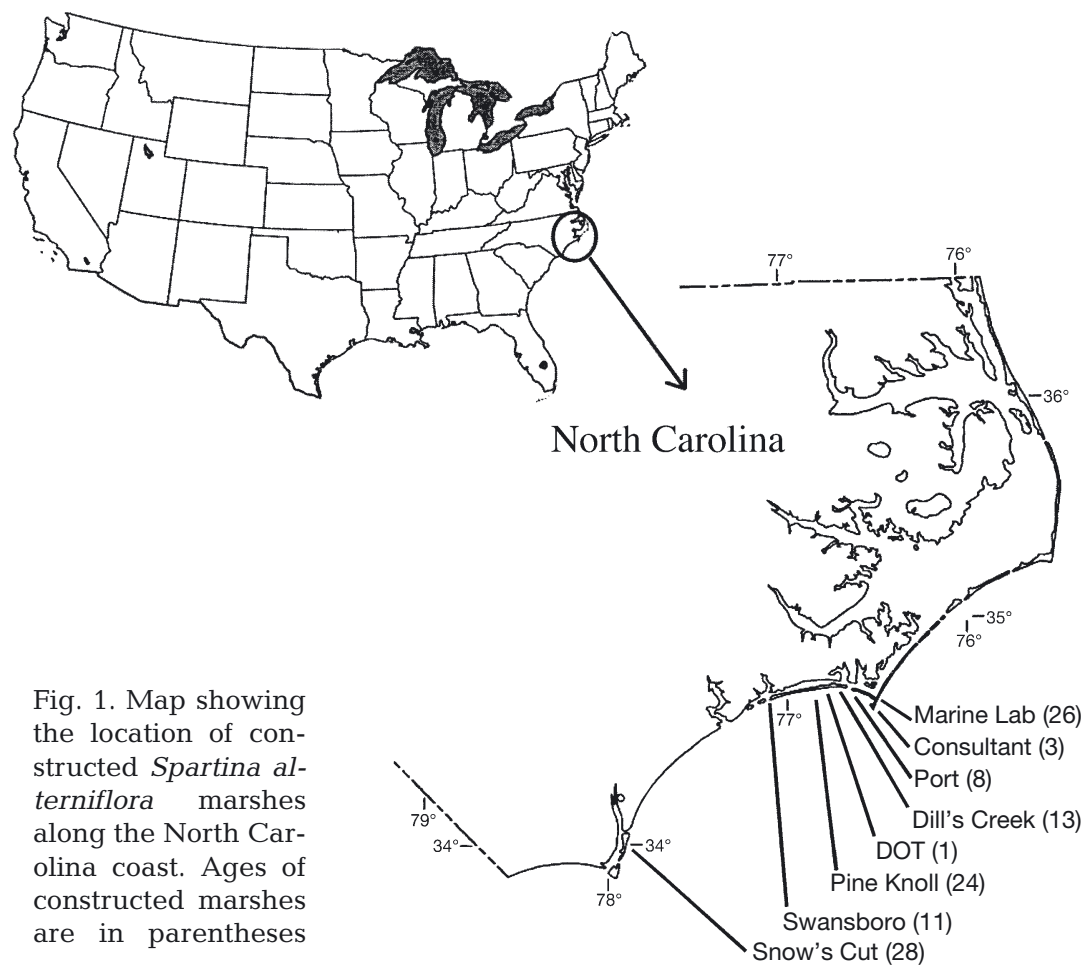

Twenty-five cores were collected from each marsh in June 1998. Sampling was stratified with 10 samples randomly collected from the levee ('tall' Spartina) zone and 15 samples collected from the marsh interior or marsh plain (medium to 'short' Spartina). Cores were preserved with $10 \%$ buffered formaldehyde and Rose Bengal (to stain the organisms) in the field, then washed through a $250 \mu \mathrm{m}$ sieve with deionized water in the lab (Sacco et al. 1994). Organisms retained on the screen were sorted, identified to the lowest possible taxon, counted, and stored in $70 \%$ ethyl alcohol. Dominant taxa consisted of the polychaetes Manayunkia aestuarina, Streblospio benedicti, and Capitella sp. Oligochaeta, Nematoda and Nereidae were not identified below this level. Whereas a $250 \mu \mathrm{m}$ mesh sieve retains most of benthic infauna, it does not quantitatively sample nematodes that are usually sampled using a $63 \mu \mathrm{m}$ mesh sieve. disturbance events (Pickett 1994). However, because our constructed marshes are relatively young $(<30 \mathrm{yr}$ old), we are familiar with changes, including disturbance history, of the 7 sites during their existence.

At each site, a nearby natural marsh with the same environmental conditions and vegetation was paired with the constructed marsh to serve as a reference site for comparison. Reference wetlands are used to set performance goals for created and restored wetlands (Brinson \& Rheinhardt 1996). By pairing each constructed marsh with its own reference marsh, we were able to minimize the effects of geomorphic position (see Table 1) that might affect benthic invertebrate succession. Soils of the constructed marshes were classified as typic psammaquents (high sand content) (USDA 1999). Natural marsh soils were classified as typic psammaquents or typic hydraquents (high clay content) (USDA 1999).

Sample collection and analysis. Infauna were sampled in June 1998 by collecting $3 \mathrm{~cm}$ diameter by $5 \mathrm{~cm}$ deep cores from each marsh. The small diameter and shallow depth of the corer likely biases sampling towards smaller organisms and leads to under-representation of larger organisms (Alphin \& Posey 2000). By collecting a greater number of cores $(n=25)$ throughout the marsh, we were able to capture the spatial variability caused by the patchiness of infauna communities that may not be accounted for by studies that collect larger but fewer cores (for example, $\mathrm{n}=7$ per marsh as in Alphin \& Posey 2000).
Thus, the results of our nematode dataset are biased towards the larger ones retained by the $250 \mu \mathrm{m}$ mesh sieve.

Infauna trophic structure was determined by classifying the organisms into the following groups: surfacedeposit feeders (Manayunkia aestuarina, Streblospio benedicti, Nereidae), subsurface-deposit feeders (Oligochaeta, Capitella sp.) and carnivores based on feeding strategy of Sacco et al. (1994). Some taxa (e.g. nematodes), because of unknown or variable feeding habits, were classified as 'unknown' in the feeding category. Table 2 contains the complete list of infauna taxa along with their trophic classification.

Characteristics of below-ground biomass and soil of constructed marshes were used to identify relationships between infauna succession and edaphic factors. Biomass and soil samples were collected from 10 of the 25 infauna sampling points (5 levee and 5 marsh plain samples each) at the same time that infauna were sampled. At each sampling point, 2 cores each $8.5 \mathrm{~cm}$ diameter by $10 \mathrm{~cm}$ deep were collected. Below-ground biomass (macro-organic matter) was collected by washing 1 core on a $2 \mathrm{~mm}$ mesh diameter screen, collecting the roots remaining on the screen and drying them at $70^{\circ} \mathrm{C}$. Macro-organic matter quality was characterized by measuring water-soluble extractives, cellulose and lignin, as described by Ryan et al. (1990). The second soil core was weighed (for bulk density), then dried and sieved through a $2 \mathrm{~mm}$ mesh diameter screen and analyzed for organic $\mathrm{C}$, nutrients $(\mathrm{N}, \mathrm{P})$ and 
Table 2. Taxa identified, trophic group classification and mean proportional density of benthic infuana in constructed and natural marshes

\begin{tabular}{|c|c|c|c|}
\hline \multirow[t]{2}{*}{ Taxon } & \multirow[t]{2}{*}{ Trophic group } & \multicolumn{2}{|c|}{ Proportional density (\%) } \\
\hline & & Constructed marsh & Natural marsh \\
\hline Oligochaeta & Subsurface $^{a}$ & 16.6 & 32.8 \\
\hline \multicolumn{4}{|l|}{ Polychaeta: } \\
\hline Manayunkia aestuarina & Surface $^{b}$ & 11.4 & 12.2 \\
\hline Streblospio bendictii & Surface & 7.1 & 9.1 \\
\hline Capitella sp. & Subsurface & 9.7 & 4.7 \\
\hline Nereidae & Surface & 3.3 & 4.1 \\
\hline Cirratulidae & Surface & 0.02 & 0.1 \\
\hline Glycera sp. & Carnivore & 0 & 0.1 \\
\hline Maldanidae & Subsurface & 0 & 0.01 \\
\hline Orbiniidae & Subsurface & 0.1 & 0.4 \\
\hline Phyllodocidae & Carnivore & 0.02 & 0.1 \\
\hline Polydora ligni & Surface & 0.3 & 0.05 \\
\hline Sabellidae & Surface & 0 & 0.02 \\
\hline Spionid sp. & Surface & 0.2 & 0.05 \\
\hline Nematoda & Unknown & 29.7 & 19.5 \\
\hline \multicolumn{4}{|l|}{ Crustacea: } \\
\hline Barnacle & Surface & 0.1 & 0.01 \\
\hline Cyathura polita & Surface & 0.1 & 0.1 \\
\hline Gammaridae & Surface & 0.1 & 0.2 \\
\hline Harpacticoid Copepoda & Unknown & 1.1 & 1.8 \\
\hline Leptochelia sp. & Surface & 4.7 & 4.0 \\
\hline Ostracoda & Unknown & 0.5 & 3.1 \\
\hline Sesarma sp. & Surface & 0.03 & 0.01 \\
\hline Uca sp. & Surface & 0.1 & 0.1 \\
\hline Crab larvae & Unknown & 0.9 & 0.1 \\
\hline Edotea sp. & Surface & 0.03 & 0.3 \\
\hline \multicolumn{4}{|l|}{ Arachnida: } \\
\hline Acarina & Unknown & 0.4 & 0.3 \\
\hline \multicolumn{4}{|l|}{ Insecta: } \\
\hline Collembola & Surface & 0.01 & 0.03 \\
\hline Ceratopogonidae & Surface & 0.9 & 0.2 \\
\hline Dolichopodidae & Carnivore & 0.3 & 0.1 \\
\hline Dipteran larvae & Surface & 0.1 & 0.03 \\
\hline Homoptera & Surface (grazer) & 0.2 & 0.01 \\
\hline Tabanidae & Carnivore & 0.02 & 0.01 \\
\hline \multicolumn{4}{|l|}{ Mollusca: } \\
\hline Bivalva & Unknown & 3.0 & 0.5 \\
\hline Gastropoda & Surface & 7.5 & 4.0 \\
\hline Melampus sp. & Surface (grazer) & 0.7 & 0.01 \\
\hline \multicolumn{4}{|l|}{ Cnidaria (Coelenterata): } \\
\hline Anemone & Carnivore & 0.6 & 0.3 \\
\hline \multicolumn{4}{|l|}{ Platyhelminthes: } \\
\hline Turbellaria & Carnivore & 0.4 & 1.5 \\
\hline Rhynchocoela (Nemeratea) & Carnivore & 0.02 & 0.1 \\
\hline $\begin{array}{l}{ }^{a} \text { Subsurface-deposit feeders } \\
\text { bSurface-deposit feeders }\end{array}$ & & & \\
\hline
\end{tabular}

particle size. Organic $\mathrm{C}$ and $\mathrm{N}$ were measured using a Perkin-Elmer $2400 \mathrm{CHN}$ analyzer. Total P was measured as orthophosphate after digestion in nitricperchloric acid (Sommers \& Nelson 1972). Sand, silt and clay were determined by the hydrometer method (Gee \& Bauder 1986).

Statistical analysis. Pair-wise $t$-tests were used to test for differences in ecological attributes between constructed and natural marsh pairs (SAS 1996). Where appropriate, test results were interpreted based on the assumption of unequal variances. All tests of significance were made at $\alpha=0.05$. Regression analysis was used to describe relationships between the measured attributes and constructed marsh age (SAS 1996). Correlation analysis, regression analysis and canonical correlation analyses were used to explore relationships between edaphic characteristics of belowground vegetation (macro-organic matter quantity and quality-lignin, cellulose, water-soluble extractives) and soil (bulk density, sand, silt, clay, organic C, N, P) 
and benthic infauna community composition (SAS 1996). Prior to analysis, the data were tested for homogeneity of variance ( $F$-max test) and log-transformed $(\log [\mathrm{x}+1])$ if needed (Sokal \& Rohlf 1995). A total of 70 macro-organic matter, soil (0 to $10 \mathrm{~cm}$ depth) and infauna samples (0 to $5 \mathrm{~cm}$ depth) were used in the analysis.

\section{RESULTS}

\section{Total density, taxon richness and dominant taxa}

The 1 and 3 yr old constructed marshes contained significantly fewer individuals and were less taxon rich than their natural marsh counterparts (Table 3). Infauna density in the $1 \mathrm{yr}$ old constructed marsh was $15 \%$ (19500 ind. $\mathrm{m}^{-2}$ ) of levels found in the natural marsh (126000 ind. $\mathrm{m}^{-2}$ ), whereas the $3 \mathrm{yr}$ old constructed marsh contained half the number of infauna (52000 ind $\mathrm{m}^{-2}$ ) as the comparable reference marsh (95000 ind. $\mathrm{m}^{-2}$ ). Taxon richness (per $7.07 \mathrm{~cm}^{2}$ core) in the 1 and 3 yr old constructed marshes was only 30 to $55 \%$ of levels found in comparable reference marshes (Table 3). Total taxa identified per marsh were also lower in the 1 (8), 3 (13) and 8 (17) yr old constructed marshes as compared to the comparable reference marshes (16 to 24) (Table 3). There was no difference in infauna density and taxon richness between older constructed marshes and reference marshes (Table 3).

Density of the 6 dominant taxa, oligochaetes, Manayunkia aestuarina, Streblospio benedicti, Capitella spp., Nereidae and nematodes, were all significantly lower in the 1 yr old constructed marsh than in the comparable reference marsh (Tables 2 \& 3). The 3 yr old constructed marsh contained significantly fewer oligochaetes, $M$. aestuarina and Nereidae than the comparable reference marsh (Tables $2 \& 3$ ). The 8, 13 and 24 yr old constructed marshes also contained fewer oligochaetes than comparable reference marshes. Densities of $S$. benedicti and Capitella sp. achieved equivalence to natural marshes relatively quickly, after 3 yr (Table 4).

Similar to total density, density of non-dominant 'other' taxa was significantly lower in the 1 and 3 yr old constructed marshes (Table 4). In these constructed marshes, the density of non-dominant taxa was $10 \%$ $\left(1200 \mathrm{~m}^{-2}\right)$ of levels found in comparable reference marshes (11000 to 12000 ind. $\mathrm{m}^{-2}$ ). Low density of 'other' taxa in 1 and 3 yr old constructed marshes was attributed to large numbers of the gastropod, the mud snail Ilyanassa sp., a surface-deposit feeder, in the reference marshes (4.4 to $9 \%$ of all organisms) but was absent, or nearly so, from the constructed marshes (0.2 to $0.3 \%)$.

Oligochaetes were the dominant taxon in natural marshes (19 to $45 \%$ ) and in constructed marshes older than $10 \mathrm{yr}(16$ to $48 \%$ ) and the tubificid Monopylephorus spp. was the most abundant oligochaete. Nematodes were the second most abundant taxon, accounting for 7 to $35 \%$ in natural marshes and 7 to $64 \%$ in constructed marshes. Manayunkia aestuarina (0 to $31 \%)$, Streblospio benedicti (1 to $18 \%$ ), Capitella sp. $(<1$ to $19 \%)$ and Nereidae ( $<1$ to $6 \%$ ) were present in lesser numbers in constructed and natural marshes.

\section{Trophic composition}

Densities of infauna trophic groups were lower in the youngest constructed marshes as compared to comparable reference marshes. The $1 \mathrm{yr}$ old constructed marsh contained significantly fewer surface- and subsurface-deposit feeders and organisms of unknown feeding preferences than the reference marsh (Table 5). The $3 \mathrm{yr}$ old constructed marsh contained fewer surface-deposit feeders, subsurface-deposit feeders and carnivores, and the density of subsurface-

Table 3. Mean total density, taxon richness and density of oligochaetes and Manayunkia estuarina of constructed (Con.) and natural (Nat.) Spartina alterniflora marshes. Multiply values by 1000 to express as density in number $\mathrm{m}^{-2}$

\begin{tabular}{|c|c|c|c|c|c|c|c|c|c|}
\hline \multirow[t]{2}{*}{ Marsh } & \multirow[t]{2}{*}{$\begin{array}{l}\text { Age } \\
(y r)^{\mathrm{a}}\end{array}$} & \multicolumn{2}{|c|}{$\begin{array}{c}\text { Density } \\
\left(\text { no. } \mathrm{m}^{-2} \times 10^{3}\right)\end{array}$} & \multicolumn{2}{|c|}{$\begin{array}{l}\text { Taxon richness } \\
\left(\text { no. } 7.07 \mathrm{~cm}^{-2}\right)\end{array}$} & \multicolumn{2}{|c|}{$\begin{array}{l}\text { Oligochaetes } \\
\left(\text { no. } \mathrm{m}^{-2} \times 10^{3}\right)\end{array}$} & \multicolumn{2}{|c|}{$\begin{array}{l}\text { Manayunkia } \\
\left(\text { no. } \mathrm{m}^{-2} \times 10^{3}\right)\end{array}$} \\
\hline & & Con. & Nat. & Con. & Nat. & Con. & Nat. & Con. & Nat \\
\hline DOT & 1 & 19 & $126^{*}$ & $2.6(8)^{b}$ & $9.0 *(19)$ & 0.2 & $35^{*}$ & 0 & $17^{*}$ \\
\hline Consultant & 3 & 52 & $95^{*}$ & $4.5(13)$ & $8.0 *(16)$ & 2.7 & $31^{*}$ & 1 & $7^{*}$ \\
\hline Port & 8 & 102 & 96 & $8.8(17)$ & $8.3 \quad(24)$ & 9.2 & $38^{*}$ & 4 & 0.1 \\
\hline Dill's Creek & 13 & 145 & 128 & $8.6(16)$ & $8.0 \quad(16)$ & 24 & $39^{*}$ & 11 & 2 \\
\hline Pine Knoll & 24 & 106 & 135 & $8.6(20)$ & $6.9 \quad(20)$ & 24 & $61^{*}$ & 5 & 14 \\
\hline Marine Lab & 26 & 118 & 125 & $9.2(20)$ & $8.6 \quad(20)$ & 16 & 24 & 37 & 33 \\
\hline Snow's Cut & 28 & 137 & 157 & 7.2 (18) & $7.8 \quad(21)$ & 67 & 58 & 42 & 42 \\
\hline
\end{tabular}


Table 4. Mean density (no. $\mathrm{m}^{-2}$ ) of Streblospio benedicti, Capitella, Nereidae, Nematoda and combined all 'Other' taxa of constructed (Con.) and natural (Nat.) Spartina alterniflora marshes

\begin{tabular}{|c|c|c|c|c|c|c|c|c|c|c|c|}
\hline \multirow{2}{*}{ Marsh } & \multirow{2}{*}{$\begin{array}{l}\text { Age } \\
(\mathrm{yr})^{\mathrm{a}}\end{array}$} & \multicolumn{2}{|c|}{ Streblospio } & \multicolumn{2}{|c|}{ Capitella } & \multicolumn{2}{|c|}{ Nereidae } & \multicolumn{2}{|c|}{ Nematoda } & \multicolumn{2}{|c|}{ Other } \\
\hline & & Con. & Nat. & Con. & Nat. & Con. & Nat. & Con. & Nat. & Con. & Nat. \\
\hline DOT & 1 & 1700 & $14500^{*}$ & 3800 & $9000^{*}$ & 100 & $7000^{*}$ & 12500 & $33500^{*}$ & 1200 & $10700^{*}$ \\
\hline Consultant & 3 & 1700 & $14500^{*}$ & 7700 & 5000 & 1700 & $6000^{*}$ & 30500 & 19500 & 1200 & $12000^{*}$ \\
\hline Port & 8 & 800 & 1300 & 10700 & $900^{* *}$ & 5000 & $2400^{* *}$ & 20000 & 34000 & 52500 & $18500^{* *}$ \\
\hline Dill's Creek & 13 & 25000 & 23000 & 4200 & 3000 & 8400 & 5900 & 3300 & 22000 & 40000 & 33000 \\
\hline Pine Knoll & 24 & 1000 & 1000 & 11100 & $5100^{* *}$ & 2300 & 3100 & 23500 & $11500^{* *}$ & 38500 & 40000 \\
\hline Marine Lab & 26 & 9000 & 9500 & 11900 & 6300 & 7100 & 7200 & 17000 & 28000 & 20500 & 17500 \\
\hline Snow's Cut & 28 & 100 & $18000^{*}$ & 200 & $13100^{*}$ & 100 & $4100^{*}$ & 9000 & 12500 & 19000 & 9500 \\
\hline
\end{tabular}

deposit feeders and carnivores was significantly lower in the $8 \mathrm{yr}$ old constructed marsh than in the natural marsh (Table 5). Surface-deposit feeders developed quickly following marsh construction as a result of colonization by Streblospio benedicti. Subsurface-deposit feeders, which consisted mostly of non-dispersing (tubificid) oligochaetes, were slower to develop than other feeding groups. Only the 26 and 28 yr old constructed marshes had densities of subsurface-deposit feeders that were comparable to reference marshes (Table 5).

Subsurface-deposit feeders were the dominant trophic group in natural marshes, accounting for 25 to $49 \%$ of total density. In natural marshes, surfacedeposit feeders, unknown feeding groups and carnivores accounted for 14 to $47 \%, 10$ to $40 \%$ and 0 to $1 \%$ of the total, respectively. Constructed marshes contained a greater proportion of unknown feeding groups (9 to $68 \%$ ), mostly nematodes that may be surface-deposit feeders, subsurface-deposit feeders or carnivores.

\section{Trajectories of infauna succession}

Density and taxon richness of infauna were low in young constructed marshes but, over time, converged towards equivalence to natural marsh infauna communities (Fig. 2). Both invertebrate density and taxon richness were significantly related to constructed marsh age $\left(r^{2}=0.89\right.$ to $\left.0.90, p<0.001\right)$, achieving equivalence to natural marshes after $8 \mathrm{yr}$. Of the 6 dominant taxa, oligochaetes and Manayunkia aestuarina exhibited a predictable increase in numbers over time (Fig. 3). Density of $M$. aestuarina increased linearly with constructed marsh age $\left(\mathrm{r}^{2}=0.65, \mathrm{p}<0.05\right)$ and achieved or exceeded equivalence to natural marshes after 8 yr. Oligochaetes also exhibited a linear increase with marsh age $\left(\mathrm{r}^{2}=0.57, \mathrm{p}<0.05\right)$, but densities did not achieve equivalence to natural marshes until after 25 yr (Fig. 3b). Other dominant taxa, Streblospio benedicti, Capitella sp., Nereidae and nematodes, did not exhibit a predictable increase in density over time. Rather, density of these taxa increased quickly,

Table 5. Mean density (no. $\mathrm{m}^{-2}$ ) of surface-deposit feeders, subsurface-deposit feeders, carnivores and unknown feeding groups of constructed (Con.) and natural (Nat.) Spartina alterniflora marshes

\begin{tabular}{|c|c|c|c|c|c|c|c|c|c|}
\hline \multirow[t]{2}{*}{ Marsh } & \multirow{2}{*}{$\begin{array}{l}\text { Age } \\
(y r)^{a}\end{array}$} & \multicolumn{2}{|c|}{ Surface feeders } & \multicolumn{2}{|c|}{ Subsurface feeders } & \multicolumn{2}{|c|}{ Carnivores } & \multicolumn{2}{|c|}{ Unknown } \\
\hline & & Con. & Nat. & Con. & Nat. & Con. & Nat. & Con. & Nat \\
\hline DOT & 1 & 2000 & $46000^{*}$ & 4000 & $44000^{*}$ & 300 & 400 & 13500 & $36500^{*}$ \\
\hline Consultant & 3 & 10500 & $37000^{*}$ & 10500 & $35500^{*}$ & 0 & $300^{*}$ & 30500 & 21000 \\
\hline Port & 8 & 40000 & $14000^{* *}$ & 21500 & $42000^{*}$ & 100 & $1800^{*}$ & 41000 & 38000 \\
\hline Dill's Creek & 13 & 79000 & $43500^{* *}$ & 28500 & $43500^{*}$ & 0 & 0 & 37000 & 41000 \\
\hline Pine Knoll & 24 & 41000 & 55000 & 36500 & $67000^{*}$ & 200 & 200 & 28000 & $13500^{* *}$ \\
\hline Marine Lab & 26 & 70500 & 60500 & 28500 & 31500 & 500 & 900 & 19000 & 34500 \\
\hline Snow's Cut & 28 & 57000 & 70500 & 67000 & 71500 & 200 & 100 & 13500 & 14500 \\
\hline
\end{tabular}



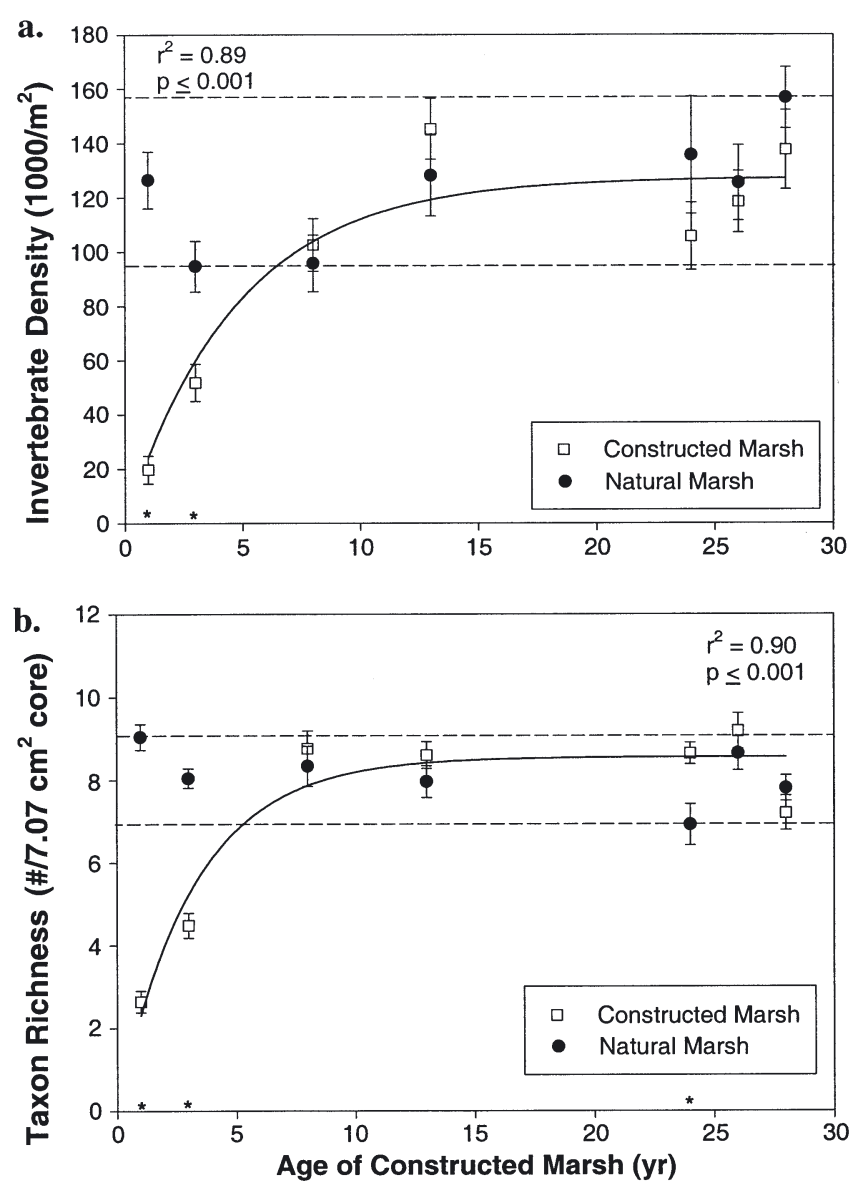

Fig. 2. (a) Density (no. $\mathrm{m}^{-2} \pm \mathrm{SE}$ ) and (b) species richness (taxa $7.07 \mathrm{~cm}^{-2}$ core $\pm \mathrm{SD}$ ) of benthic infauna along a chronosequence of constructed salt marshes and natural reference marshes. Asterisks (*) indicate that the constructed and paired reference marsh are significantly different $(p<0.05)$ according to Student's $t$-test. Dashed lines represent the range of values measured in the natural marshes

achieving or exceeding equivalence to natural marshes within $7 \mathrm{yr}$ following marsh construction (Table 4).

Proportional density of oligochaetes increased along the chronosequence of constructed marshes, from $1 \%$ of the total in the $1 \mathrm{yr}$ old marsh to $48 \%$ in the $28 \mathrm{yr}$ old marsh. Proportional density of Manayunkia aestuarina, another taxon with non-dispersing larvae, also increased with constructed marsh age. M. aestuarina were absent from the $1 \mathrm{yr}$ old constructed marsh but increased to $31 \%$ of the total in the 26 and $28 \mathrm{yr}$ old marshes. Other taxa such as nematodes and Capitella sp. were most abundant in the youngest constructed marshes and decreased with marsh age. Proportional density of nematodes, for example, was greatest (64\%) in the $1 \mathrm{yr}$ old constructed marsh and lowest $(7 \%)$ in the 28 yr old marsh. Similarly, proportional density of Capitella sp. was $19 \%$ in the $1 \mathrm{yr}$ old constructed marsh, decreasing to $<1 \%$ in the $28 \mathrm{yr}$ old constructed marsh. Overall, proportional density of oligochaetes was 2 times greater (32\%) in natural marshes than in constructed marshes (16\%) (Table 2). Constructed marshes, in contrast, contained relatively more Capitella sp. and Nematoda than natural marshes (Table 2).

Density of surface- and subsurface-deposit feeding infauna were also significantly related to constructed marsh age $\left(r^{2}=0.71\right.$ to 0.73$)$. The number of surfacedeposit feeders increased over time, achieving or exceeding equivalence to natural marshes within $10 \mathrm{yr}$ following marsh construction (Fig. 4a). Subsurfacedeposit feeders developed at a slower rate than surface-deposit feeders (Fig. 4b) and did not achieve equivalence to natural marshes until 25 yr after marsh construction.

The proportion of unknown feeding groups decreased with constructed marsh age, from $68 \%$ in the 1 yr old marsh to $9 \%$ in the $28 \mathrm{yr}$ old marsh. Conversely, the proportion of surface-deposit feeders in-
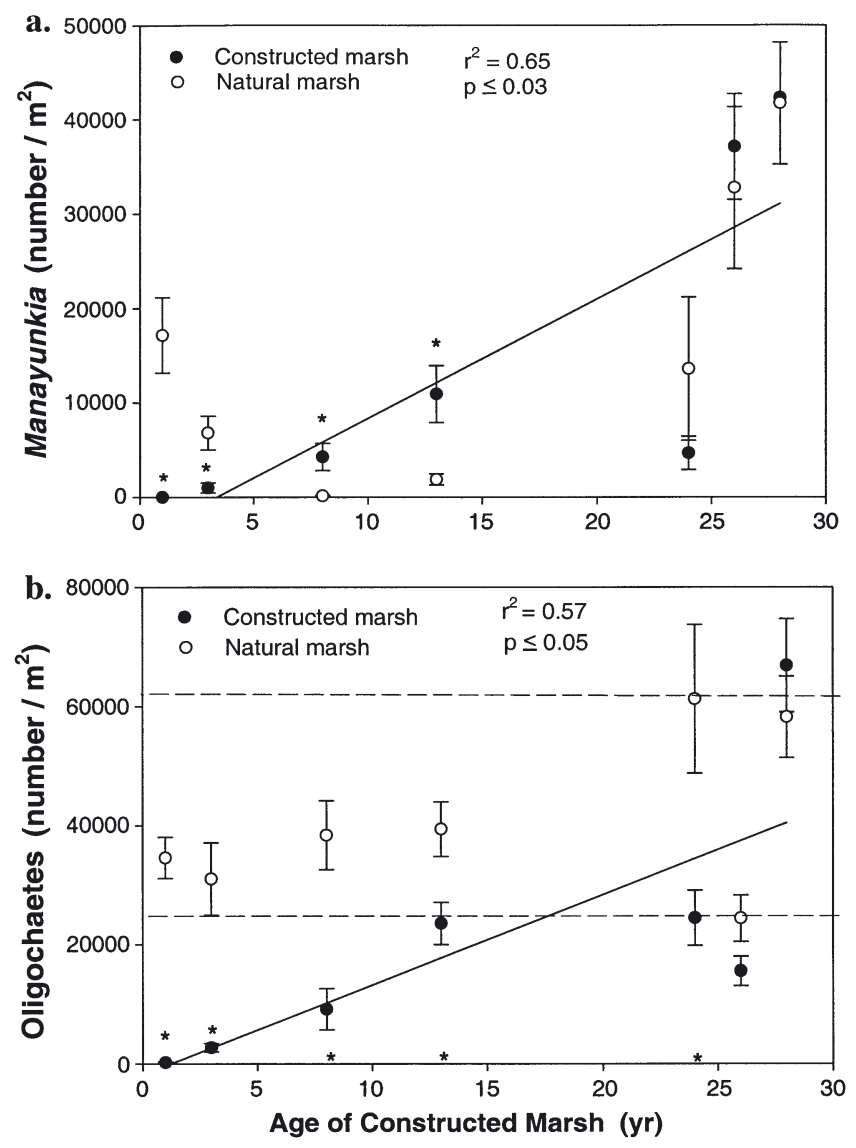

Fig. 3. Density (no. $\mathrm{m}^{-2} \pm \mathrm{SE}$ ) of (a) Manayunkia aestuarina and (b) oligochaetes along a chronosequence of constructed salt marshes and natural reference marshes. Asterisks $\left.{ }^{*}\right)$ indicate that the constructed and paired reference marshes are significantly different $(\mathrm{p}<0.05)$ according to Student's $t$-test. Dashed lines represent the range of values measured in the natural marshes 
creased from $10 \%$ in the $1 \mathrm{yr}$ old constructed marsh to $39-59 \%$ in constructed marshes greater than $5 \mathrm{yr}$ old. No clear trend was identified with respect to the proportion of subsurface-deposit feeders and constructed marsh age.

Trajectories describing successional development of oligochaetes and Manayunkia aestuarina were linear, whereas trajectories for surface- and subsurfacedeposit feeders was best described by a non-linear (exponential rise to maximum) curve. Because oligochaetes are a major component of the subsurfacedeposit feeding trophic group, one would expect that both groups would be represented by a similarly shaped curve. Thus, the asymptotic increase in density of subsurface-deposit feeders over time must be caused by rapid colonization by other subsurfacedeposit-feeding taxa such as Capitella sp. (Table 4). Increased numbers of surface-deposit feeders relative to M. aestuarina (a surface-deposit feeder) was attributed to rapid colonization of constructed marshes by another surface-deposit feeder, Streblospio benedicti. It is interesting to note that a linear-regression model best described successional development of taxa (oligochaetes, $M$. aestuarina) that lack a planktonic dispersal stage. A curvilinear model was better for describing succession of infauna trophic groups because these groups contain taxa with both dispersing and non-dispersing larvae.

\section{Edaphic factors and infauna community composition}

Trajectories of infauna succession were linked to development of other ecological attributes such as plant biomass, soil organic $\mathrm{C}, \mathrm{N}$, silt and clay, which increase over time following marsh construction (Craft et al. 1999, 2003). For example, soil bulk density and macro-organic matter (0 to $10 \mathrm{~cm}$ depth) were significantly correlated with attributes of the infauna community, including total density, taxon richness, domi-
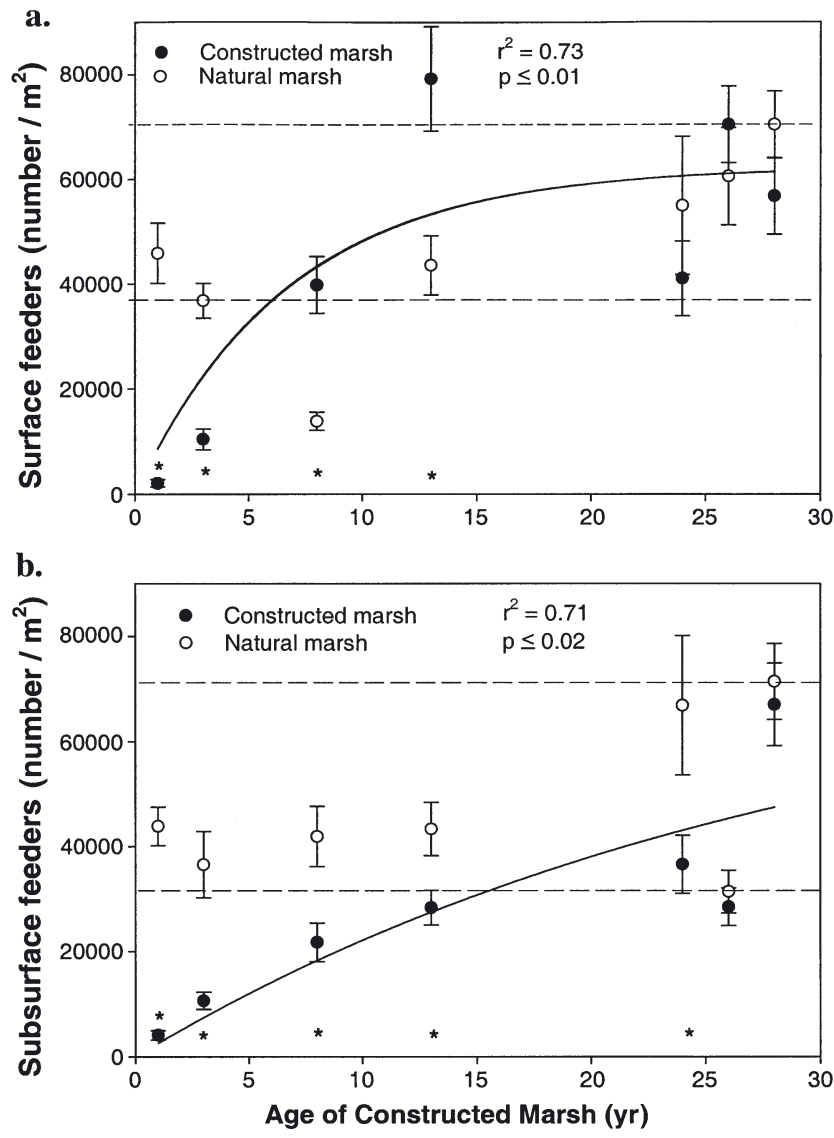

Fig. 4. Density (no. $\mathrm{m}^{-2} \pm \mathrm{SE}$ ) of (a) subsurface-deposit feeders and (b) surface-deposit feeders along a chronosequence of constructed salt marshes and natural reference marshes. Asterisks $\left({ }^{*}\right)$ indicate that the constructed and paired reference marsh are significantly different $(p<0.05)$ according to Student's $t$-test. Dashed lines represent the range of values measured in the natural marshes

nant taxa (oligochaetes, Manayunkia aestuarina) and trophic groups (surface- and subsurface-deposit feeders) (Table 6). Soil characteristics including organic $C_{\text {, }}$ $\mathrm{N}$, silt and clay (0 to $10 \mathrm{~cm}$ depth), which increase dur-

Table 6. Significant $(\mathrm{p}<0.05)$ correlation coefficients between benthic infauna community composition and soil-belowground biomass characteristics of constructed Spartina alterniflora marshes $(n=70)$. MOM = macro-organic matter

\begin{tabular}{|c|c|c|c|c|c|c|c|}
\hline & Density & $\begin{array}{l}\text { Taxon } \\
\text { richness }\end{array}$ & Oligochaetes & $\begin{array}{c}\text { Manayunkia } \\
\text { aestuarina }\end{array}$ & $\begin{array}{c}\text { Streblospio } \\
\text { benedicti }\end{array}$ & $\begin{array}{l}\text { Surface } \\
\text { feeders }\end{array}$ & $\begin{array}{l}\text { Subsurface } \\
\text { feeders }\end{array}$ \\
\hline Bulk density & -0.58 & -0.45 & -0.55 & -0.61 & - & -0.61 & -0.55 \\
\hline Organic carbon & 0.45 & 0.45 & 0.51 & 0.61 & - & 0.52 & 0.45 \\
\hline Total nitrogen & 0.45 & - & 0.48 & 0.62 & - & 0.51 & 0.49 \\
\hline Sand & -0.50 & - & -0.50 & -0.55 & -0.48 & -0.53 & -0.49 \\
\hline Silt & 0.51 & - & 0.53 & 0.57 & 0.55 & 0.52 & 0.52 \\
\hline Clay & 0.47 & - & 0.44 & 0.50 & 0.38 & 0.53 & 0.43 \\
\hline MOM & 0.51 & 0.44 & 0.46 & 0.51 & - & 0.47 & 0.47 \\
\hline Lignin & - & 0.38 & - & - & - & - & - \\
\hline Extractives & - & -0.36 & - & - & - & - & - \\
\hline
\end{tabular}


ing salt marsh ecosystem development, were also positively associated with infauna community development (Table 6). There was no correlation between infauna density and aboveground biomass or stem density of Spartina based on comparison of mean values from each marsh (Craft et al. 2003). In constructed marshes, density of Streblospio benedicti was positively correlated with silt and clay content and negatively correlated with sand, but was not correlated with other soil characteristics such as bulk density, C or N (Table 6). Taxon richness of infauna also was correlated with quality of accumulating macro-organic matter. Taxon richness was positively associated with lignin, which increased with constructed marsh age and negatively correlated with water-soluble extractives that were greater in MOM of young constructed marshes.

Similar to the simple correlations, canonical correlation analysis revealed that infauna density was associated mostly with soil characteristics whereas taxon richness was more strongly associated with macroorganic matter quality. The first canonical variable, which was highly correlated with infauna density $(\mathrm{r}=0.98)$, was positively correlated with macro-organic matter $(r=0.64)$, soil organic $C(r=0.62), N(r=0.60)$, silt $(r=0.71)$ and clay $(r=0.65)$, and negatively correlated with bulk density $(\mathrm{r}=-0.79)$ and sand $(\mathrm{r}=-0.70)$. The second canonical variable, which represented taxon richness $(r=0.93)$, was positively correlated with lignin $(r=0.60)$ and cellulose $(r=0.42)$ and negatively correlated with water-soluble extractives $(r=-0.74)$.

Macro-organic matter and soil organic $\mathrm{C}$ were the best single variables for predicting infauna density following marsh construction. Macro-organic matter and soil organic $\mathrm{C}$ ( 0 to $10 \mathrm{~cm}$ depth) explained 40 and $38 \%$ of the variation, respectively, in infauna density of individual soil cores $(\mathrm{n}=70)$, and a non-linear model fit the data better than a linear model (Fig. 5). Based on the regressions, it appears that approximately $500 \mathrm{~g} \mathrm{MOM}$ $\mathrm{m}^{-2}$ or $0.5 \% \mathrm{C}\left(500 \mathrm{~g} \mathrm{~m}^{-2}\right)$ is sufficient to support constructed marsh infauna densities that are comparable to densities measured in our natural marshes (Fig. 5). Above these 'threshold' concentrations, infauna densities remain relatively uniform across a broad range of MOM (500 to $4000 \mathrm{~g} \mathrm{~m}^{-2}$ ) and soil organic C (0.5 to $8 \%$ ) levels.

Non-linear regression of soil organic C and MOM were also the single best predictors of taxon richness and density of oligochaetes, surface-deposit feeders and subsurface-deposit feeders. Organic C explained $42 \%(\mathrm{p}<0.0001)$ of the variation in taxon richness, whereas MOM explained $52 \%$ of the variation $(\mathrm{p}<0.0001)$. The non-linear model based on soil organic $\mathrm{C}$ also was useful for predicting density of oligochaetes $\left(\mathrm{r}^{2}=0.33, \mathrm{p}<0.05\right)$, subsurface deposit feeders $\left(\mathrm{r}^{2}=0.32, \mathrm{p}<0.05\right)$ and surface deposit feeders $\left(\mathrm{r}^{2}=0.40, \mathrm{p}<0.01\right)$.

\section{DISCUSSION}

\section{Infauna succession}

Total density and taxon richness of benthic infauna achieved equivalence to natural marshes within $8 \mathrm{yr}$ following marsh construction (Fig 2). Our findings suggest relatively rapid development of benthic infauna numbers, which is supported by other studies of constructed estuarine marshes. For example, macrofauna density in marshes of Winyah Bay (South Carolina) were 4 times greater in an 8 yr old Spartina alterniflora marsh (19 943 ind. $\mathrm{m}^{-2}$ measured in 1988) as compared to a $4 \mathrm{yr}$ old marsh (4628 ind. $\mathrm{m}^{-2}$ ) (LaSalle et al. 1991). Repeated sampling of 3 Winyah Bay marshes (established in 1977, 1981 and 1988, respectively) in 1993 and 1998 revealed that, whereas infauna density var-
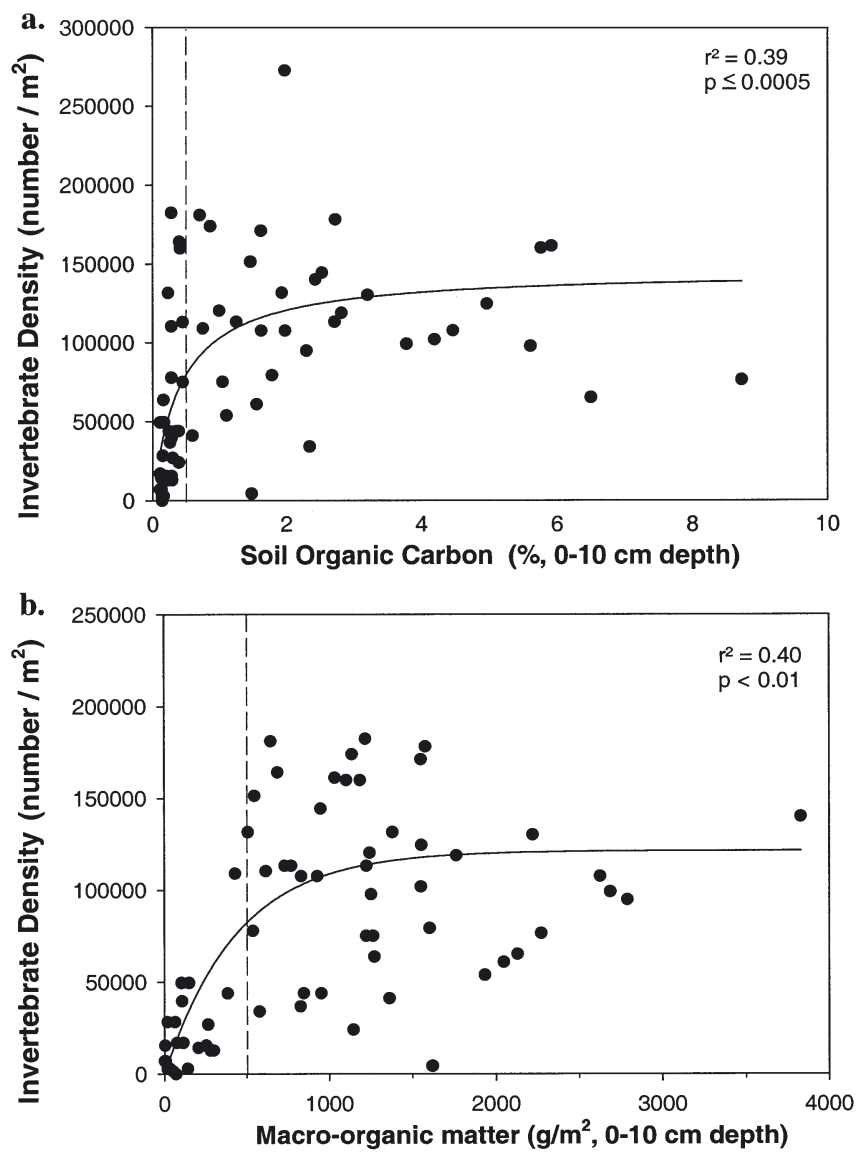

Fig. 5. Relationship between infauna density (no. $\mathrm{m}^{-2}$ ) and (a) $\%$ soil organic C (0 to $10 \mathrm{~cm}$ depth) and (b) macro-organic matter ( $\mathrm{g} \mathrm{m}^{-2}, 0$ to $10 \mathrm{~cm}$ depth) in constructed salt marshes. $\mathrm{N}=70$ samples 
ied between years, proportional density of dominant species was constant regardless of marsh age or year of sampling (Alphin \& Posey 2000). Infauna communities of Salicornia-vegetated marshes created in southern California also developed quickly, within 5 to $10 \mathrm{yr}$ (Talley \& Levin 1999).

Some studies, however, suggest that infaunal communities develop much more slowly. Sacco et al. (1994) reported that $16 \mathrm{yr}$ after creation, some constructed marshes contained fewer numbers of infauna than comparable natural marshes. Craft et al. (1999) sampled infauna 10 yr apart on 2 constructed and 2 natural Spartina alterniflora marshes in North Carolina. Density of infauna increased between 1986 and 1995 in both constructed marshes, but held steady in the 2 natural marshes. In contrast, repeated annual sampling by Simenstad \& Thom (1996) over a 3 yr period following construction of a brackish-water (0 to $15 \mathrm{ppt}$ ) Carex lyngbyei estuarine marsh in Puget Sound, Washington, yielded no clear evidence of increasing density and succession of infauna communities. In the west coast study, it is possible that the young age of the marsh $(4 \mathrm{yr})$ and the short ( $3 \mathrm{yr})$ sampling interval made it difficult to identify trajectories of benthic infauna succession on this marsh.

Streblospio benedicti and Capitella sp. quickly colonized constructed marshes. Density of these taxa achieved equivalence to natural marshes within $5 \mathrm{yr}$ following marsh creation (Table 4). Previous studies noted that $S$. benedicti and Capitella sp. are early colonizers of constructed Spartina alterniflora marshes (Moy \& Levin 1991, Levin et al. 1996, Posey et al. 1997, Alphin \& Posey 2000). Capitella sp. produces planktotrophic larvae that readily disperse (Levin et al. 1996) and, therefore, are among the first to colonize a site. $S$. benedicti produces both planktotrophic and lecithotrophic (non-dispersing) larvae (Levin \& Huggett 1990). In this study, we did not identify larval forms of $S$. benedicti, but rapid colonization by this species following marsh construction is consistent with immigration by the planktonic form. Manayunkia aestuarina and tubificid oligochaetes, in contrast, lack a planktonic dispersal stage (Levin et al. 1996) and, therefore, these taxa may be slower to colonize the marsh. In our study, Monopylephorus sp., a non-dispersing tubificid, was the most abundant oligochaete taxon and, as a result, there were significantly fewer oligochaetes in constructed marshes less than 25 yr old as compared to natural marshes (Table 3). Manayunkia densities were lower only in the 1 and 3 yr old constructed marshes (Table 3 ). Levin et al. (1996) observed that a 4 yr old constructed $S$. alterniflora marsh in North Carolina contained fewer oligochaetes than a nearby natural marsh. Tubificid oligochaetes also were less abundant in 16 mo to
$10 \mathrm{yr}$ old created Salicornia marshes than in natural Salicornia marshes of southern California (Talley \& Levin 1999).

Some studies of older constructed marshes, however, suggest that oligochaete and Monopylephorus spp. densities achieve equivalence faster than the time scales reported above. Alphin \& Posery (2000), for example, reported that Monopylephorus spp. was the dominant taxon in 3 constructed marshes ranging in age from 6 to $19 \mathrm{yr}$ old. Similarly, a literature review of salt marshes constructed on dredged material revealed no difference in the density of oligochaetes between constructed and natural marshes (Streever 2000). In the review paper, however, abundance of polychaetes and crustaceans was significantly greater in natural versus constructed marshes.

In contrast to subsurface deposit-feeding oligochaetes and the surface deposit-feeder Manayunkia, whose densities exhibited linear trajectories over time (Fig. 3), density of surface and subsurface deposit feeders increased asymptotically (Fig. 4). Also, trajectories of surface and subsurface deposit feeders exhibited better 'goodness-of-fit' versus time than trajectories of individual taxa. Faster pace of development of surfaceand subsurface deposit feeders relative to oligochaetes and Manayunkia reflects rapid colonization of constructed marshes by other surface and subsurface deposit-feeding organisms. For example, densities of the subsurface deposit feeder, Capitella sp., achieved or exceeded equivalence to natural marshes within 3 yr following marsh construction. Density of surface deposit-feeders, Streblospio benedicti, Nereidae and bivalves, also quickly achieved or exceeded equivalence to natural marshes (Table 2). Subsurface deposit feeders developed more slowly than surface deposit feeders (Fig. 4b). Other studies noted that densities of subsurface deposit feeders are slow to develop following marsh construction, primarily because of slow development of subsurface deposit-feeding tubificid oligochaetes (Sacco et al. 1994, Levin et al. 1996) caused, possibly, by low MOM and soil organic matter (Moy \& Levin 1991, Minello \& Zimmerman 1992, Sacco et al. 1994, Levin et al. 1996, Craft 2000).

Infauna density of our natural and constructed marshes greater than $5 \mathrm{yr}$ of age ranged from 96000 to 157000 organisms $\mathrm{m}^{-2}$. These values are higher than densities reported for other natural and constructed marshes of the southeastern US coast, but comparable to densities in Spartina foliosa and Salicornia-vegetated marshes in southern California (Levin et al. 1998, Talley \& Levin 1999) (Table 7). High infauna densities in this study relative to other atlantic coast studies reflects (1) smaller sieve size $(250 \mu \mathrm{m})$ used in this study relative to other studies (LaSalle et al. 1991, Alphin \& Posey 2000) and (2) nematodes that were 
Table 7. Comparison of benthic infauna densities (no. $\mathrm{m}^{-2}$ ) of constructed and natural Spartina alterniflora marshes

\begin{tabular}{|c|c|c|}
\hline & Constructed marshes & Natural marshes \\
\hline $\begin{array}{l}\text { LaSalle et al. }(1991) \\
(4 \text { and } 8 \text { yr old, }>0.500 \mu \mathrm{m})\end{array}$ & $5000-20000$ & Not measured \\
\hline $\begin{array}{l}\text { Moy \& Levin }(1991) \\
(1-3 \text { yr old, }>300 \mu \mathrm{m})\end{array}$ & $19600(450000)^{\mathrm{a}}$ & $15000(760000)^{\mathrm{a}}$ \\
\hline $\begin{array}{l}\text { Minello \& Zimmerman (1992) } \\
(2-5 \text { yr old, }>500 \mu \mathrm{m})\end{array}$ & $1900-56000$ & $13000-70000$ \\
\hline $\begin{array}{l}\text { Sacco et al. }(1994) \\
(1-16 \text { yr old, }>250 \mu \mathrm{m})\end{array}$ & $16000-49000$ & $18000-69000$ \\
\hline $\begin{array}{l}\text { Levin et al. }(1996) \\
(1-4 \text { yr old, }>300 \mu \mathrm{m})\end{array}$ & $6000-47000$ & $37000-65000$ \\
\hline $\begin{array}{l}\text { Levin et al. (1998) } \\
\text { ( } S \text {. foliosa marshes, }>300 \mu \mathrm{m} \text { ) }\end{array}$ & Not measured & 122000 \\
\hline $\begin{array}{l}\text { Craft et al. }(1999) \\
(21,25 \text { yr old, }>250 \mu \mathrm{m})\end{array}$ & $31000-102000$ & $19000-31000$ \\
\hline $\begin{array}{l}\text { Talley \& Levin }(1999)^{\mathrm{b}} \\
(5-10 \text { yr old, }>300 \mu \mathrm{m})\end{array}$ & $88000-290000$ & $22000-117000$ \\
\hline $\begin{array}{l}\text { Alphin \& Posey }(2000) \\
(6-25 \text { yr old, }>500 \mu \mathrm{m})\end{array}$ & $3000-13000$ & Not measured \\
\hline $\begin{array}{l}\text { This study } \\
(1-28 \text { yr old, }>250 \mu \mathrm{m})\end{array}$ & $19000-145000$ & $96000-157000$ \\
\hline \multicolumn{3}{|c|}{$\begin{array}{l}\text { a Numbers in parentheses are meiofauna, organisms retained on a } 63-300 \mu \mathrm{m} \text { sieve } \\
{ }^{\mathrm{b}} \text { Salicornia-vegetated marsh }\end{array}$} \\
\hline
\end{tabular}

constructed marsh had significantly more Capitella sp., Nereidae and 'other' taxa as compared to the natural marsh, and the 24 yr old marsh contained more Capitella sp. and nematodes (Table 4). Levin et al. (1996) tracked infauna community succession on the same $8 \mathrm{yr}$ old constructed marsh for 4 yr following marsh construction, and found that Capitella sp. was the first taxon to colonize the site. Some studies suggest that density of Capitella sp. is positively related to percent sand (see Zipperer 1996 and Toomey 1997, cited in Levin \& Talley 2000) but we did not observe a similar relationship in this study. In the $8 \mathrm{yr}$ old constructed marsh, another factor that may contribute to greater density of Capitella sp., Nereidae and other taxa may be the construction of a tidal creek in this marsh (but not in other marshes) that facilitates tidal flushing and promotes soil oxygenation and recruitment. The 24 yr old constructed marsh also was sampled by Craft et al. (1999) in 1995 and, in that study, the

qualitatively enumerated in this study but were not counted in other studies (Sacco et al. 1994, Levin et al. 1996).

Three marsh sites (Dill's Creek, Pine Knoll, Snow's Cut) sampled as part of this study in 1998 were compared with infauna data collected by Sacco et al. (1994) in 1986. Both studies used similar sampling methods and sieve size $(250 \mu \mathrm{m})$. Total density measured in 1998 was much greater (106000 to 157000 ind. $\mathrm{m}^{-2}$ ) than in 1986 (17500 to 69900 ind. $\mathrm{m}^{-2}$ ), partially because we quantitatively enumerated nematodes, whereas Sacco et al. (1994) did not. However, densities of individual taxa (e.g. oligochaetes, Manayunkia, Streblospio benedicti) also were lower in Sacco et al's. (1994) study as compared to this study. Overall, taxonomic and trophic composition was similar in the constructed marshes and their natural marsh counterparts in 1986 and 1998, except for the Dill's Creek constructed marsh, which was 2 yr old in 1986 and contained essentially no oligochaetes at that time. Alphin \& Posey (2000) also sampled the Snow's Cut constructed marsh in November 1998. Taxonomic composition of the infauna community was similar to results of Sacco et al. (1994) and this study except that a tanaid (Heterotanais sp.) was the dominant taxa, accounting for $46 \%$ of total density.

Density of some taxa was consistently greater in several constructed marshes. For example, the $8 \mathrm{yr}$ old constructed marsh also contained significantly more Capitella sp., but not nematodes, than the nearby reference marsh.

\section{Edaphic factors and succession}

In constructed marshes, infauna density was strongly associated with below-ground biomass and soil properties, especially bulk density and organic C (Table 6). Regression analysis revealed that soil organic $\mathrm{C}$ and MOM (0 to $10 \mathrm{~cm}$ depth) were the single best predictors of infauna density (Fig. 5) and taxon richness $\left(\mathrm{r}^{2}=\right.$ 0.42 and 0.52 , respectively). Other studies of constructed and natural salt marshes report that infauna density is positively associated with below-ground biomass (Lana \& Guiss 1992, Craft 2000, Levin \& Talley 2000) and soil organic C (Sarda et al. 1995, Levin et al. 1998, Craft 2000, Levin \& Talley 2000). In a comprehensive review paper, Levin \& Talley (2000) reported that infauna density is most frequently associated with soil organic matter. For example, in natural and constructed southern California marshes vegetated with Spartina foliosa and Salicornia, soil organic matter was positively associated with total density and density of oligochaetes and polychaetes. Canonical correspondence analysis of the same dataset revealed that soil organic content was the dominant component of the 
first principal axis explaining infauna community variation (Levin \& Talley 2000). In a study of Salicorniavegetated constructed marshes of southern California, infauna density of some macrofaunal taxa was positively related to soil organic matter (SOM), whereas in natural marshes density of some taxa was negatively related to SOM (Talley \& Levin 1999). Reduced densities of infauna in constructed marshes has been attributed to low soil organic $\mathrm{C}$ and high bulk density, which provides food, refuge and ease-of-burrowing, and is characteristic of older, high organic matter natural marsh soils (Moy \& Levin 1991, Levin et al. 1996).

Total density and density of individual taxa (oligochaetes, Manayunkia aestuarina, Streblospio benedicti) and trophic groups (surface and subsurface deposit feeders) also was significantly associated with particle size (Table 6). Density of $S$. benedicti was much greater in the $13 \mathrm{yr}$ old constructed marsh than its natural marsh counterpart as compared to all other marshes (Table 4). Constructed and natural marsh soils from the 13 yr old site also contained more silt plus clay (constructed marsh $=38 \%$, natural marsh $=66 \%, 0$ to $10 \mathrm{~cm}$ depth), than the other constructed (6 to $11 \%$ ) and natural marshes (4 to $52 \%$ ). Sacco et al. (1994) also observed greater densities of $S$. benedicti in these 2 marshes than in 5 other constructed and natural and marsh pairs, which all had coarser, sandier soils. Other published studies found that infauna density is positively correlated with fine-grained sediment (Lana \& Guiss 1991) and negatively correlated with percent sand (Levin \& Talley 2000). Levin \& Talley (2000) reported that, in Spartina foliosa marshes, density of total macrofauna and enchytraeid oligochaetes were inversely correlated with percent sand, whereas in Salicornia-vegetated marshes, the reverse was true.

In contrast to infauna density, which was positively related to organic matter quantity, taxon richness was more strongly related to quality of MOM. Canonical correlation analysis revealed that taxon richness was positively correlated with lignin $(r=0.60)$ and cellulose $(r=0.42)$, and negatively correlated with water-soluble extractives $(r=-0.74)$ in MOM. Lignin is relatively unpalatable to heterotrophic organisms (Melillo et al. 1982, Stevenson 1994), so the positive correlation between infauna density and lignin may be attributed to physical rather than nutritional properties of macroorganic matter. Lignin decomposes slowly, persisting in the soil, enhancing soil structure that possibly contributes to development of infauna communities.

We also measured aboveground characteristics of Spartina in the same marshes. Because Spartina was sampled at the end of the growing season (October) rather than in the summer (June), when infauna, MOM and soils were sampled, we were unable to quantitatively evaluate the effects of aboveground biomass and stem density on infauna succession. Comparison of mean values from the 7 constructed marshes, however, indicated that infauna density was correlated with soil properties (organic C, total N) but not with aboveground biomass or stem density (Craft et al. 2003). Similar to infauna density, aboveground biomass of $S$. alterniflora also required 8 yr to achieve equivalence to natural marshes (Craft et al. 2003), and the 1 and 3 yr old constructed marshes contained significantly less biomass (300 to $700 \mathrm{~g} \mathrm{~m}^{-2}$ ) than comparable natural marshes (900 to $1200 \mathrm{~g} \mathrm{~m}^{-2}$ ). Belowground biomass took longer to develop, as 15 yr elapsed before belowground biomass of constructed marshes developed to levels found in natural marshes (Craft et al. 2003). These findings suggest that belowground biomass (MOM) of Spartina is more important than aboveground biomass for development of infauna communities.

Other published studies evaluating relationships between infauna communities and edaphic conditions report few correlations between above-ground characteristics of marsh vegetation but much stronger correlations with below-ground characteristics. Levin \& Talley (2000) cite a variety of studies where infauna density and density of various taxa were positively correlated with below-ground biomass of both constructed marshes (Levin \& Talley 2000) and natural marshes (Osenga \& Coull 1983, Rader 1984, Lana \& Guiss 1992, Levin \& Talley 2000). In some studies, however, several infauna taxa were negatively correlated with belowground biomass (Capehart \& Hackney 1989, Levin \& Talley 2000).

\section{CONCLUSIONS}

Most attributes of infauna community structure and function achieved equivalence to natural marshes within 8 yr following marsh construction. Oligochaetes and subsurface-deposit feeders, however, required much longer (25 yr) before densities developed to levels that were comparable to natural marshes. Development of oligochaetes and subsurface deposit feeders depended on accumulation of sufficient soil organic matter $\left(0.5 \%\right.$ or $\left.500 \mathrm{~g} \mathrm{~m}^{-2}\right)$ and macro-organic matter $\left(500 \mathrm{~g} \mathrm{~m}^{-2}\right)$ to support densities found in natural marshes. The 'success' of most wetland creation projects is evaluated on the basis of vegetation attributes such as percent cover measured after a $5 \mathrm{yr}$ period. Slow development of the benthic infauna community, especially oligochaetes, following salt marsh construction suggests that wetland managers should consider the pace of development of infauna communities when setting performance criteria for salt marsh mitigation projects. 
Acknowledgements. Thanks to B. Casey, C. Chiang, B. Penhallegan, G. Anglin and C. Day for picking invertebrates, J. Vymazal for constructing the graphs, and 3 anonymous reviewers for thoughtful reviews of an earlier version of the manuscript. This research was supported by a grant from the US Environmental Protection Agency's (EPA) Science To Achieve Results (STAR) program through Grant \#826111-010 . Although the research described in the article has been funded wholly or in part by the US EPA's STAR, it has not been subjected to any EPA review and therefore does not necessarily reflect the views of the Agency, and no official endorsement should be inferred.

\section{LITERATURE CITED}

Alphin TD, Posey MH (2000) Long-term trends in vegetation dominance and infaunal community composition in created marshes. Wetlands Ecol Manage 8:317-325

Brinson MM, R Rheinhardt (1996) The role of reference wetlands in functional assessment and mitigation. Ecol Appl 6:69-76

Broome SW, Seneca ED, Woodhouse WW Jr (1988) Tidal salt marsh restoration. Aquat Bot 32:1-22

Broome SW, Craft CB, Toomey WA Jr (2001) Soil organic matter effects on infaunal community structure in restored and created tidal marshes. In: Weinstein MP, Kreeger DA (eds) Concepts and controversies in tidal marsh ecology. Kluwer Academic Publishers, Dordrecht, p 737-747

Capehart AA, Hackney C (1989) The potential role of roots and rhizomes in structuring salt marsh benthic communities. Estuaries 12:119-122

Craft CB (2000) Co-development of wetlands soils and benthic invertebrate communities following salt marsh creation. Wetlands Ecol Manage 8:197-207

Craft CB, Reader JM, Sacco JN, Broome SW (1999) Twentyfive years of ecosystem development of constructed Spartina alterniflora (Loisel) marshes. Ecol Appl 9:1405-1419

Craft CB, Megonigal JP, Broome SW, Stevenson RJ, Freese R, Cornell J, Zheng L, Sacco J (2003) The pace of ecosystem development of constructed Spartina alterniflora marshes. Ecol Appl (in press)

Gee GW, Bauder JW (1986) Particle-size analysis. In: Methods of soil analysis. Part 1. Physical and mineralogical methods. Agronomy Monograph No. 9. American Society of Agronomy-Soil Science Society of America, Madison, WI, p 383-411

Karr JR (1991) Biological integrity: a long neglected aspect of water resource management. Ecol Appl 1:66-84

Kerans BL, Karr JR (1994) A benthic index of biotic integrity (B-IBI) for rivers of the Tennessee Valley. Ecol Appl 4: $768-785$

Lana PC, Guiss C (1991) Influence of Spartina alterniflora on structure and temporal variability of macrobenthic associations in a tidal flat of Paranagua Bay (southeastern Brazil). Mar Ecol Prog Ser 73:231-244

Lana PC, Guiss C (1992) Macrofauna-plant biomass interactions in a euhaline salt marsh in Paranagua Bay (SE Brazil). Mar Ecol Prog Ser 80:57-64

Lang G, l'Eplattenier G, Reymond O (1989) Water quality in rivers of western Switzerland: application of an adaptable index based on benthic invertebrates. Aquat Sci 51: $224-234$

LaSalle MW, Landin MC, Sims JG (1991) Evaluation of the flora and fauna of a Spartina alterniflora marsh established on dredged material in Winyah Bay, South Carolina. Wetlands 11:191-208
Lenat DR (1988) Water quality assessment of streams using a qualitative collection method for benthic macroinvertebrates. J N Am Benthol Soc 7:222-233

Levin LA, Huggett DV (1990) Implications of alternative reproduction modes for seasonality and demography in an estuarine polychaete. Ecology 71:2191-2208

Levin LA, Talley D (2000) Influences of vegetation and abiotic environmental factors on salt marsh invertebrates. In: Weinstein MP, Kreeger DA (eds) Concepts and controversies in tidal marsh ecology. Kluwer Academic Publishers, Dordrecht, p 661-707

Levin LA, Talley D, Thayer G (1996) Succession of macrobenthos in a created salt marsh. Mar Ecol Prog Ser 141:67-82

Levin LA, Talley TS, Hewitt J (1998) Macrobenthos of Spartina foliosa (Pacific Cordgrass) salt marshes in southern California: community structure and comparison to a Pacific mudflut and Spartina alterniflora (Atlantic Smooth Cordgrass) marsh. Estuaries 21:129-144

Melillo JM, Aber JD, Muratore JF (1982) Lignin and nitrogen control of hardwood leaf litter decomposition dynamics. Ecology 63:621-626

Minello TJ, Webb JW Jr (1997) Use of natural and created Spartina alterniflora salt marshes by fisheries species and other aquatic fauna in Gavelston Bay, Texas, USA. Mar Ecol Prog Ser 151:165-179

Minello TJ, Zimmerman RJ (1992) Utilization of natural and transplanted Texas salt marshes by fish and decapod crustaceans. Mar Ecol Prog Ser 90:273-285

Moy LD, Levin LA (1991) Are Spartina marshes a replaceable resource? A functional approach to evaluation of marsh creation efforts. Estuaries 14:1-16

Osenga GA, Coull BC (1983) Spartina alterniflora Loisel root structure and meiofaunal abundance. J Exp Mar Biol Ecol 67:221-225

Pickett STA, Parker VT (1994) Avoiding the old pitfalls: opportunities in a new discipline. Restoration Ecol 2:75-79

Posey MH, Alphin TD, Powell CM (1997) Plant and infaunal communities associated with a created marsh. Estuaries 20:42-47

Rader DN (1984) Salt marsh benthic invertebrates: small scale patterns of distribution and abundance. Estuaries 7:413-420

Ryan MG, Melillo JM, Ricca A (1990) A comparison of methods for determining proximate carbon fractions of forest litter. Can J For Res 20:166-171

Sacco JN, Seneca ED, Wentworth T (1994) Infaunal community development of artificially established salt marshes in North Carolina. Estuaries 17:489-500

Sarda R, Foreman K, Valiela I (1995) Macrofauna of a southern New England salt marsh: seasonal dynamics and production. Mar Biol 121:431-445

Scatolini SR, Zedler JB (1996) Epibenthic invertebrates of natural and constructed marshes of San Diego Bay. Wetlands 16:24-37

Simenstad CA, Thom RM (1996) Functional equivalency trajectories of the Gog-Le-Hi-Te estuarine wetland. Ecol Appl 6:38-56

Sokal RR, Rohlf FJ (1995) Biometry. WH Freeman, San Francisco

Sommers LE, Nelson DW (1972) Determination of total phosphorus in soils: a rapid perchloric acid digestion procedure. Soil Sci Soc Am 36:902-904

Spieles DJ, Mitsch WJ (2000) Macroinvertebrate community structure in high- and low-nutrient constructed wetlands. Wetlands 20:716-729

SAS (Statistical Analysis Systems) (1996) SAS user's guide. SAS Institute, Cary, NC 
Stevenson FJ (1994) Humus chemistry: genesis, composition and reactions. John Wiley \& Sons, New York

Streever WJ (2000) Spartina alterniflora marshes on dredged material: a critical review of the ongoing debate over success. Wetlands Ecol Manage 8:295-316

Talley TS, Levin LA (1999) Macrofaunal succession and community structure in Salicornia marshes of southern California. Estuar Coast Shelf Sci 49:713-731

Toomey WA Jr (1997) The effect of soil organic matter quantity on salt marsh functioning and infaunal commu-

Editorial responsibility: Otto Kinne (Editor),

Oldendorf/Luhe, Germany nity structure. Thesis, North Carolina State University, Raleigh, NC

USDA (United States Department of Agriculture) (1999) Soil Taxonomy. Agricultural Handbook No. 436. Natural Resources Conservation Service, US Government Printing Office, Washington, DC

Zipperer VR (1996) Ecological effects of the introduced cordgrass, Spartina alterniflora on the benthic community structure of Willapa Bay, Washington. Thesis, University of Washington, Seattle, WA

Submitted: November 26, 2002; Accepted: May 21, 2003 Proofs received from author(s): July 16, 2003 